\title{
The Reform of Public Administration in Northern Ireland: From Principles to Practice
}

\author{
Paul Carmichael and Colin Knox ${ }^{1}$ \\ University of Ulster
}

April 2005

"The choice for Ulster has always been limited democracy with stability or unlimited democracy without stability" (NI civil servant, anon.)

\section{Political Studies : Vol 53 (4): 772-792}

Contact details

Professor Paul Carmichael

Professor Colin Knox

School of Policy Studies

University of Ulster

Newtownabbey

Co Antrim

Northern Ireland

BT37 0QB

00442890368896

00442890366667

p.carmichael@ulster.ac.uk

cg.knox@ulster.ac.uk

\footnotetext{
${ }^{1}$ The authors wish to acknowledge the support for the research in this paper from the ESRC Devolution and Constitutional Change Programme. We would also like to thank anonymous referees for helpful comments on the paper.
} 


\section{ABSTRACT}

The system of public administration in Northern Ireland has, perhaps inevitably, been of secondary concern amid over 30 years of inter-communal sectarian strife. Faced with combating terrorism, successive UK governments wouldn't consider reform of the Province's local public administration, pending a resolution of the wider constitutional imbroglio. Consequently, much of the system atrophied, becoming progressively more cumbersome and ill-equipped to deal with the requirements of modern government. Moreover, to help minimize charges of sectarian discrimination, quangos provided many public services, compounding the 'democratic deficit' of Direct Rule. In 1998, the Belfast (Good Friday) Agreement, offered a breakthrough in the search for a durable settlement that could command cross community support. As part of subsequent devolved Executive's 'Programme for Government', a Review of Public Administration (RPA) was launched to consider sub-regional governance arrangements with a view to enhancing democratic accountability and improving efficiency through streamlining the current arrangements. To that end, the Review has been committed to adhering to clear principles on which any credible reform should be based. While devolution itself has proved fitful, the work of the RPA has continued apace. Although embarking on reforms within functioning devolution is ministers' preferred option, there is a determination to continue the reform process irrespective of the present impasse. This paper outlines the issues, values and concepts that might shape the principles for conducting a Review before considering the particular context within Northern Ireland and the impediments to overhauling the present arrangements and speculating on the likely outcome (ENDS). 
The structure and operation of Northern Ireland's wider system of public administration were accorded a lowly priority by successive British Governments throughout 'the Troubles'. With murder and mayhem threatening to engulf them, Northern Ireland Office ministers were preoccupied with managing the most intractable and wearisome corner of the UK's territorial estate. As the temporary expedient of Direct Rule matured into 'permanent impermanence', any meaningful overhaul was effectively embargoed. Consequently, while recognition of the need for reform enjoyed rare universal consent of the key protagonists, ministers felt little inclination to immerse themselves in thankless upheaval, the inevitable outcome of which would be controversial, divisive and problematic. However, the Belfast (Good Friday) Agreement (1998) lifted this extended moratorium and, in their 'Programme for Government', Northern Ireland's new political masters launched a 'Review of Public Administration' in 2002. Moreover, despite the subsequently fitful experience of devolution, their resolve has survived the re-imposition of Direct Rule. Thus, in the medium term, there is every prospect of substantial reform notably sub-regional governance in Northern Ireland.

This paper seeks to accomplish two key objectives. First, it outlines the key issues, values and concepts that inform the development of principles for reappraising the continuing viability of any system of public administration. Second, it considers the particular context obtaining within Northern Ireland and the associated impediments to overhauling the present arrangements, speculating on the revised configuration likely to emerge. 


\section{Issues, Values and Concepts - Developing Principles for Reform}

\section{From Local Government to Local Governance}

In observing a shift from a welfare to a regulatory state, several commentators in the 1980s referred to the rise of a post-Fordist regime. 'Fordist' mass production, large hierarchically organised business organizations, mass consumption and state intervention gave way to flexible, small batch and demand-led production, segmented marketing, a rise of small and medium enterprises, labour market fluidity and a growing marginalised part-time temporary work force (Rhodes, 1997, p.173). Such changing values in global political economy have implied changing roles for government, especially at sub-national level (Stoker, 1989). Most European countries have experienced local government reorganization in the last three decades albeit enormously varied in scope and impact, with a high incidence of fundamental reforms and rapid changes (Dente and Kjellberg, 1988). Just as the expansion of the public sector had obvious consequences for regional local government structures in the $20^{\text {th }}$ century so now, the 'regulatory state' must similarly remodel, subject to the exigencies of territorial management, especially in regions that constitute a contested domain. The watchwords of the regulatory state flexibility, fragmentation and marketisation of public services - have had a noticeable impact on regional and sub-regional levels via a process of decentralisation. Globalisation raises questions over the role of regional and local institutions within a wider international framework (Mawson, 1998, p.236). The assumption of self-sufficiency in many multi-purpose local government systems, namely, that when given a task, any local 
authority has to undertake or provide it directly, is no longer automatic - the 'enabling authority' idea with its purchaser-provider split is commonplace for many services. That more rapidly changing societies need a flexible and changing pattern of response has become received wisdom. At the heart of the ensuing maelstrom, local government is at the "crossroads between society, politics and administration" (p.4) and might be expected to bear the brunt of any changes that occur, be they incremental, seismic or otherwise.

The introduction of regional tiers inevitably entails consequences for local government (and governance) including the possibility of fundamental overhauls of such structures to better suit the new dispensation. As the Council of Europe (CDLR, 2002a) outlines, "restructuring of territorial authorities has to be guided by a comprehensive vision of theory of governmental structure." (Appendix 1, Section 2). The design of sub-national territorial authorities may be drawn in relation to a number of parameters: size, functions, autonomy and mode of operation. In turn, their relationship with the system of subregional governance revolves around similar considerations. However, there is no instructor's manual for operationalising such a 'comprehensive vision'. Moreover, there is little consensus on how any reform might proceed with no generally accepted solutions to the problem of the 'best' structure for local government. The map of European local government offers all kinds of variations. ... The very few studies carried out up to now show us contradictory and heterogeneous results. They all depend on the kind of services included in the analysis, the type of demographic structure, the distribution of power within the political system (central, federal, asymmetrical federal), the number of tiers of government, the 
level of public expenditure, the type of competencies established for each level of government, and those specifically corresponding to local government, and finally, the kind of political culture within each context (CDLR, 2001, para.39).

Definitional difficulties apart, promoting one objective (e.g. 'efficiency') at the expense of another (e.g. 'democracy') is a political problem that requires a political decision. The CDLR observed candidly - if unhelpfully for the would-be reformer - that "research cannot decide these questions, but it can offer analysis to be taken into consideration in the decision-making process, mainly to avoid unfounded decisions" (CDLR, 2001, para.28). To the debate have been joined searching questions over the very requirement for local government in contemporary society. The post-Fordist stress on market processes and citizens being consumers as distinct from political actors "downgraded the role of local government considerably in terms of traditional notions of local democracy (Cram and Richardson, 1993, p.18). Going further, in a not entirely mischievous interrogative, Pierre and Peters (2000) provocatively enquired "Does (local) government still matter?" Their question forces a re-examination of first principles, always advisable if genuinely committed to a fundamental process of reform. Assuming that it does matter, Bovaird, Loeffler and Parrado-Diez (2002) pose alternative questions reflecting "new sets of expectations from citizens in their locality" (p.2). Hence: "When does local government still matter? What functions could local authorities share with other stakeholders?" (our emphasis). In recognizing the changing reality of the governmental landscape of the local state, Bovaird et al nonetheless contend, if rather banally, that local authorities "still have a very powerful problem-solving capacity with regard to some 
issues in some contexts" (p.14). Consequently, across Europe, "new networks are also developing vertically between levels of government. There seems to be a desire both at central and sub-national levels to transform traditional hierarchical relationships more into co-operative relationships, or even partnerships" (p.19). Traditional modes of decision-making and delivery have changed.

In proclaiming a new world of local governance, even the UK Government has acknowledged local authorities' pre-eminence. "Councils are ideally placed to work with government, their communities and the wider range of public, private and voluntary sector bodies who operate at local level and who need to come together if these challenges are to be successfully addressed" (DETR, 1998, p.79, cited in Stewart, 2003, p.15). A renaissance of the political dimension of local authorities is discernible. For example, Bovaird et al (2002) note a new concern for old values such as equity, ethics, trust and transparency which go beyond the '3Es' of NPM (economy, efficiency and effectiveness). There are multiple stakeholders' approaches to public services (design, production and evaluation), to problems in the local community, and to the decision mechanisms by which strategies should be made. To solve - or at least better manage wicked issues, use will be made of coordinating instruments e.g. strategic plans and partnerships. ICT, such as virtual networks / e-governance, will grow in significance. Concurrently, it is likely that the shift to governance will be joined by efforts to reinforce those areas of local public administration which have emerged in the 'local governance era' as particularly weak. These include in many (but not all) European countries: the role of politicians in community 
leadership; the role of political parties in civic management; the role of professionals in innovations around service co-production; and, the role of managers in developing the capacity of alternative service providers in the community (p.235).

\section{Criteria for Reform}

Despite the lack of consensus on their relative importance, it is possible to establish some basic principles so that those charged with making political judgments might be reasonably informed in their deliberations and determinations. According to the European Charter of Local Self-Government, a prerequisite of local democracy is a clear division of responsibilities between central and local authorities, the assigning of financial resources of their own to local authorities, commensurate with the tasks for which they are responsible, and freedom for them to decide how to use these. Further, it commits signatories to apply "basic rules guaranteeing the political, administrative and financial independence of local authorities ... [embodying] the conviction that the degree of selfgovernment enjoyed by local authorities may be regarded as a touchstone of genuine democracy" (Norton, 1994, p.19). However, a dichotomy exists between countries that consider their local authorities as service delivery institutions and others that see municipalities as mainly political and representative institutions. Thus, for the CDLR "Democratic quality and efficiency are elements that should be confined in the best possible manner (note 7). ... In striking that balance, there are many ways in which democratic participation can be expressed, not only in the electoral arena. Indeed, there 
are connections between participation and service delivery, for example, where usergroups of citizens are created to evaluate the type and quality of services delivered" (CDLR, 2001, para.9). Historical circumstances, local specificities and/or value judgments yield different approaches to a common dilemma: what is the 'ideal' size for local authorities? Ideologies, mentalities and interests inform the debate whose considerations include efficiency, democracy, promotion of economic development, and distribution though, since these are inherently normative evaluations, securing agreement on a conceptual framework still less a blueprint is elusive (paragraph 12). Thus, whereas "the assignment of territory, competency and functions between levels of government should not be a shibboleth to the past, nor to a particular economic or political theory", tensions exist between

activity spaces which form the basis of participation and technical and bureaucratic criteria for optimal administrative design. In geographical terms this relates to the question of how the administrative space is bounded. The ideal is of an activity space which is precisely matched by administrative boundaries; that is, 'truly bounded'. In this case people's personal lives and contact patterns give a natural 'sense of community' which encourages in a direct way a high level of participation in administration: the two reinforce each other. However, under and over bounding also occur (Bennett, 1989, pp.33-5) (see Figure 1 which illustrates the 'bounding' concept).

'Bounding' gives an important means of approaching the territorial structure of administration, particularly by which its reform can be developed. For decades, securing 
'bounding' has been associated with the objective of increasing size. And yet, as Derek Senior's (1969) dissenting memorandum to the Report of the Redcliffe-Maud Commission on English local government argued: "no objective basis exists on which to attribute any material significance to population size as a factor in any way influencing the performance of local government [Vol.2 p.268]". Indeed, while administrative economies of scale to induce efficiency are theoretically possible, bureaucratic overload, distance from the consumer, the difficulties of participation, and adaptation of decisions to needs has led to a dominance of practical inefficiency through diseconomies of scale with size and consequent alienation of the population served. Contending that administrative systems are "naturally subject to obsolescence", Bennett observed the "new fashion is flexible decentralisation - smaller scale and the importance of individuals over collectives but also flexible aggregation, that is, a means of linking small units and their competencies and financial resources to gain economic/technical efficiency" (p.51). Examples would include the experience within England's metropolitan counties after 1986, or Scotland and Wales after 1992. The parallels with the broader notion of the differentiated polity are striking (see Rhodes, 1997; Ladner, 2005). 


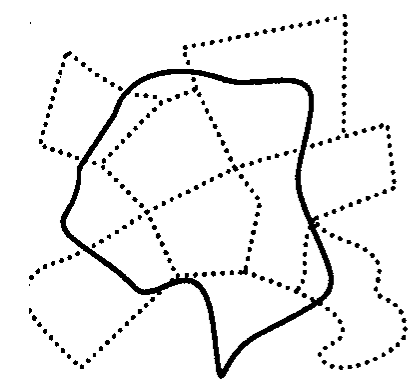

Under bounded

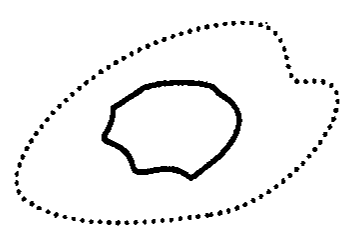

Over-bounded

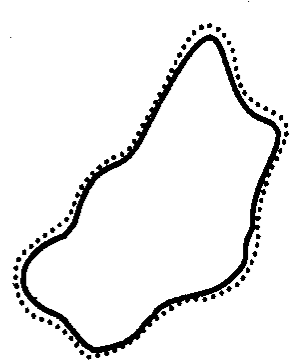

Truly-bounded

Administrative spaces (dotted lines)

Activity spaces (solid lines)

Figure 1. Forms of bounding of administrative spaces

Source: Bennett (1989, p.35) 
Local government's primordial role, like any polity, reflects a sense of common identity among its citizens which at its most basic may be defined as the consciousness that they have more in common with each other than they have with people living beyond their community boundary. Such consciousness is the sine qua non of a democracy. In de Tocqueville's aphorism: "man creates kingdoms and republics but townships seem to spring from the hand of God" (cited in Sharpe, 1988, p.91). In truth, however, the rationale for local government has always had both functional and non-functional origins. It depends which role has the priority - i.e. reflector of the subjective community or provider of services. While reconciling "the two desiderata simply by pitching the local government system at its smallest feasible scale" is possible, the "functional range is far too narrow for what most Western states regard as being appropriate for local government. And, in any event, such self-contained communities no longer exist, given the functional revolution and urbanization/sprawl" (Sharpe, 1988, p.91). Given the political dimension of change, rational efficiency arguments rarely explain local government structural modernization anywhere, including the UK (pp.94-5).

Various national reports made "it fairly clear that, primarily, the size of a local authority is a function of the services expected from it" (Zehetner, quoted in Norton, 1994, p.38). However, reflecting Europe's north/south dichotomy, charges of functional obsolescence are less valid in those states based on the Napoleonic model since the primacy of local government is its political cum representative role. “...freed from the incubus of functionality, [they] can survive". Also, the "art of colonizing the centre - via national parties and the cumuls des mandates principle" - doesn't obtain in northern Europe. 
Those elements at the Centre may also prefer the status quo of weak local government since their position is de facto stronger (p.97).

Small authorities were encouraged to form joint bodies to exercise functions requiring large areas and resources, delegate functions upwards, contract services out and adopt other means by which limitations of smallness might be overcome. But the result could be that although communal powers were maintained in principle, effective communal control of key services was lost (p.38).

Also, in joint compact or partnership arrangements, there can be problems of coherence or 'joined-up-ness'. By contrast, however, in the non-Napoleonic group, including the UK as "the extreme case" (p.38), growing public pressure for fairness, minimum standards and equality for all in the provision of public services may dilute local government's role as a representative body (Sharpe, 1988, p.100). In many ways, this is a testament to the fact that local authorities throughout the British Isles have always been more 'administrative' than 'governmental' given their lack of general competence (notwithstanding the recent introduction of 'well-being' powers), and reflects a longstanding debate within the UK over the intrinsic value of local forms of governance which became crystallized around essentially two poles. Utilitarian reformers like Jeremy Bentham maintained that "local government units should be organized so as to efficiently undertake administrative functions according to the rules determined by a popularly elected national parliament" (Chandler, 1991, p.29). Within this tradition of liberal centralism, the administrator Edwin Chadwick envisaged a system of local government as an 'agent' for the centre (known as 'the principal') charged with providing minimum 
national standards. Chadwick was deeply hostile to what he identified as entrenched power for a minority and spoke of the "fallacy that local government is self-government" (cited in MacKenzie, 1961, p.8). If somewhat strange an outlook for a liberal ostensibly committed to a diffusion of political power within the polity, the widespread albeit rather trivial examples of corruption prevalent at the time nourished such views. In contrast, others such as Joshua Toulmin Smith, with localist ideas of organic evolution, advanced the notion of partnership between the centre and localities believing local selfgovernment to be the "rock of our safety as a free state". Nonetheless, while Toulmin Smith et al "probably prevented the wholesale destruction of parish government", the liberal onslaught eventually triumphed and local government underwent substantial reform and consolidation in terms of its structural configuration and functional responsibilities (Chandler, 1991, p.30). Thereafter, the triumph of liberal centralism "justified generations of British administrators in continuing reorganizations which had little regard to the principles of local social responsibility. It also cut Britain off from the constitutionalism of the continent" (Norton, 1994, p.26). More recently, Pratchett (2004) considered the debate in terms of the 'new localism' as a policy approach in the UK. Replete with references to 'earned autonomy' and 'constrained discretion', 'new localism' resonates closely with Benthamite utilitarianism. Whatever additional powers accorded to local authorities, 'new localism' has done "little to shift power relations in favour of localities” (p.371). At best, Labour's “"new localism' may have managed to clarify some of the complexities that bedevil central-local relations [but] its capacity to resolve the dilemma seems limited" (p.373) 
In another departure from European practice, British 'exceptionalism' witnessed growing use of 'special purpose' authorities that burgeoned under Conservative Governments after 1979. The arrangements post-abolition of the Greater London Council and Metropolitan County Councils, as well as the Area Boards in Northern Ireland, typify such bodies. The resultant "criss-crossing boundaries of service authorities" was described as 'organised chaos' by Owens and Norregaard (1991, pp.8-9). A rationale for such a configuration is offered from economic theory on optimum size that predicts a model in which the local level is characterised by a multitude of partly overlapping (in a spatial sense) public or semi-public units, each providing specific services (pp.8-9). However, there are limits to the proliferation of separate authorities. The resultant misconceptions distort considerations of structural reform of British local government. In the 1990s, whether by ministerial fiat in Scotland and Wales, or through England's tortuous 'independent' Local Government Commission, reorganization was hampered by an unseemly mix of political expediency, dubious provenance and procedural muddle. The result, argued Stewart (2003), was that "while one expects that form should follow functions, in the reorganization process, form preceded functions and structure came before purpose. .... The phrase 'unitary authority' is misleading. All it means is that there is a single tier of local government, not that unitary authorities bring together all the powers of government exercised at local level or even those exercised through local organizations" (p.184). The outcome is that lower tiered and unitary authorities in the UK are some "ten times larger in population than their equivalents in Europe" (p.43), reflecting the assumptions of sizeism prevalent within British public administration. Local authorities are viewed as agencies for the provision of service despite there being no clear link between size and 
efficiency/effectiveness. As Stewart lamented, a "moment's consideration of European local government might have caused reflection. .... Both the sense of community and the requirements of services are multi-leveled and do not fit a single tier" (p.184).

A final but critical consideration is finance. Owens and Norregaard (1991) identify two principal types of authority - comprehensive and constrained. Comprehensive authorities have powers over both spending and revenue. Constrained authorities can determine the allocation of spending but not the overall level of budget/tax revenues (pp.62-63). More than ever before, British local authorities (outside Northern Ireland and, before nationalization of business rating in 1993, a handful of mainland authorities which possessed high non-domestic ratebases) exemplify the latter, their overwhelming dependency on central government grant leaving them hostage to the capricious 'gearing effect'. Transparency is a necessary condition of accountability with the balance of funding making "an enormous difference" (House of Commons Select Committee (HC, 1998, cited in Stewart, 2003, p.228). The argument is not so much about local autonomy as it is about local accountability. Drastic change in the balance of funding warrants new sources of local taxation (p.228).

\section{Lessons for Undertaking Reform}

The foregoing review is the necessary precursor to examining 'real world' situations. Theoretical abstractions notwithstanding, a distillation of the literature yields several key lessons that bear on any review exercise. Above all, the prime lesson, as the CDLR 
stressed, is that any decisions on reform rest ultimately on subjective, political judgments. Basically, it is inconceivable that political factors would not colour (even subliminally) outcomes. Even in a 'normal' context, the calculus of crude party political advantage compromises dispassionate technocratic solutions; in divided societies or where the state's very legitimacy may be contested, such considerations assume immeasurably heightened significance. For example, the effects of investing new functions with elected local councils are potentially contentious. Similarly, reconfiguring boundaries entails immediate implications for the party political complexion of new local authorities.

Beyond weighing political impacts, however, several second order factors - in effect, the 'comprehensive vision' to which the CDLR referred - merit consideration for, despite the susceptibility to political machinations, some concession should be made to ensuring objective criteria exist before embarking on change. First, intending reformers must recognize a new post-Fordist reality. Government through most-purpose local authorities has been transformed into a variegated pattern of governance in which figure not only traditional local authority units but also an array of other public, private and community/voluntary organizations. In particular, the emergence of partnership arrangements as a means of raising popular engagement with the policy process has been striking in recent years, firmly established within the received wisdom of what constitutes good government. Second, reflecting Bennett's notion of 'bounding', there is a need to ensure that any revised administrative boundaries relate to activity spaces. Third, also related to bounding, is size. Despite lip-service paid to local government's role in ensuring a sense of community identity which usually favour smaller units, these appear 
subordinate to the requirement of optimising functional capacity, which favour larger units. Thus, in reconciling the two, the balance lies towards the large end of the size spectrum, particularly in the case of local authorities with a wider range of functions. European evidence suggests, however, that seeking a 'one size fits all' solution does not work and that reconciling sense of community and functional efficiency demands multiple tiers. Fourth, while economic theory suggests a fragmented model of 'organised chaos' in terms of the configuration of local units, practicalities demand substantial consolidation. Finally, in intergovernmental relationships, there is the perennially vexed issue of finance. Simply, transparency demands realism in resource allocation, aligning functional responsibilities with financial capacity.

What has become clear in the reform process is that local community politics matter in Northern Ireland in the prolonged absence (or sporadic functioning) of a regional tier. The strength of local identity, evident within emasculated councils, defies imposition of a 'one size fits all' solution favoured by Westminster and Whitehall through direct rule ministers. These push and pull tensions are being played out in a number of ways as the reform of public administration progresses. There has been a political backlash against attempts to 'direct' councils towards accepting a 7 council 'optimal solution for service delivery' (OFMDFM, 2005: 40). Local politicians are deeply suspicious of proposals which now favour the retention of a plethora of non-departmental public bodies, albeit with improved accountability. Equally, the reformers have suggested that Executive Agencies should remain untouched - decisions on their future are to be left for a returning devolved Assembly. All of this smacks of regulatory capture by a reform team 
comprising civil servants perceived to be 'looking after their own', overseen by direct rule ministers who hold an over-simplified view of administrative reform based on rational 'solutions'. It is to the detail of the reform process that we now turn.

\section{Public Administration in Northern Ireland and its Reform}

\section{The Status Quo}

Several factors ensure that the system of public administration in Northern Ireland differs in crucial respects from that within the rest of the UK. On a practical level, population (c. $1.7 \mathrm{~m}$ inhabitants) coupled with its geographic extent ensure an idiosyncratic governmental configuration and associated delineation of functions. Politically, however, a contested constitutional status demands that solutions reflect both the history and distinctiveness of the Province's status within the Union and relationship with its southern neighbour, as well as seeking to reconcile a bitterly divided community. Since 1972, though a short-term palliative pending a more durable agreed settlement, Direct Rule instead became a long-term political fix aimed at containment. The 'permanent impermanence' (Knox, 1996) it entailed ushered in a system of political administration whose baffling intricacies inspired little public confidence still less comprehension. Progressively, both the Senior Civil Service and unelected ministerially-appointed quangos acquired an enhanced role and disproportionate influence over the formulation, development and implementation of public policy in Northern Ireland, creating a tighter and more intimate policy network than in Scotland or Wales, and in which administrative imperatives and interests predominated. The resultant "technocracising of politics" (Ditch 
and Morrissey, 1979, p.111) reflects the effective absence of pluralist liberal democracy as commonly understood.

While the Troubles were the catalyst for macro political change in Northern Ireland, dissatisfaction with the existing sub-regional arrangements had been mounting since the War. The inability of the local government system to provide services efficiently precipitated the growth of ad hoc statutory bodies and the removal and centralization of council functions (Knox, 2003, p.461). Eventually, pressure built to overhaul a Victorian creation comprising too many small councils, inadequately resourced through a limited rate base and overly dependent on central grant for their income (Hayes, 1967). Although the Stormont Government responded with a series of consultations (NIG, 1966, 1969), the subsequent criticisms of local government outlined in the Cameron Report (1969) prompted the appointment in 1969 of an independent Review Body on Local Government, chaired by Sir Patrick Macrory.

The problem facing the Review Body was to construct a local government system appropriate to a situation in which Stormont - at that time the Northern Ireland equivalent of central government - had been or would be allocated all those major services which, in other parts of Britain, are regarded as wholly or partly the responsibility of local authorities (Alexander, 1982, p.50).

In what amounted to a quantum leap in residualisation that characterised Northern Ireland's local government, Macrory envisaged a two-tier structure: a lower tier of district councils, with Stormont serving as the de facto top tier of local government, 
coterminous with the Province, and responsible for 'regional' services accompanied by an array of area boards. However, the imposition of Direct Rule superceded the reform, creating what was dubbed the 'Macrory Gap' - having removed erstwhile local services, these were now subject to the decisions of British rather than Northern Ireland ministers. Consequently, in what would become the limiting case of extended central control, trends which had seen a further upward shift of functional competence from lower to upper tiers of local government in Great Britain (to the counties in England and Wales and regions in Scotland) were reflected in Northern Ireland. That is, the formal system of local government would comprise 26 district councils albeit "best thought of as the lower tier in a system that simply lacks a democratically elected higher level of local government" (Hampton, 1991, p.54). While the map of district boundaries themselves largely satisfied Bennett's concept of 'bounding', the addition of several layers of other bodies - Area Boards, regional bodies (and their sub-divisions) and Parliamentary constituency boundaries - vitiated any overall sense of being fully bounded (see Figures 2-5, below).

Quangos became the mainstay of Northern Ireland's governance, providing most public services and accounting for two thirds of the devolved budget. While they accentuated the democratic deficit, quangos proved valuable - amidst the quagmire of sectarianism for administering and delivering public service largely free from controversy. However, questions of legitimacy and accountability are accompanied by concern over efficiency given the plethora of bodies. Simply, Northern Ireland is over governed - or, to be precise, over-administered. Lammenais' (1848) adage: “apoplexy at the centre and anaemia at the periphery", encapsulates the state of public administration within Northern Ireland after 1973. 


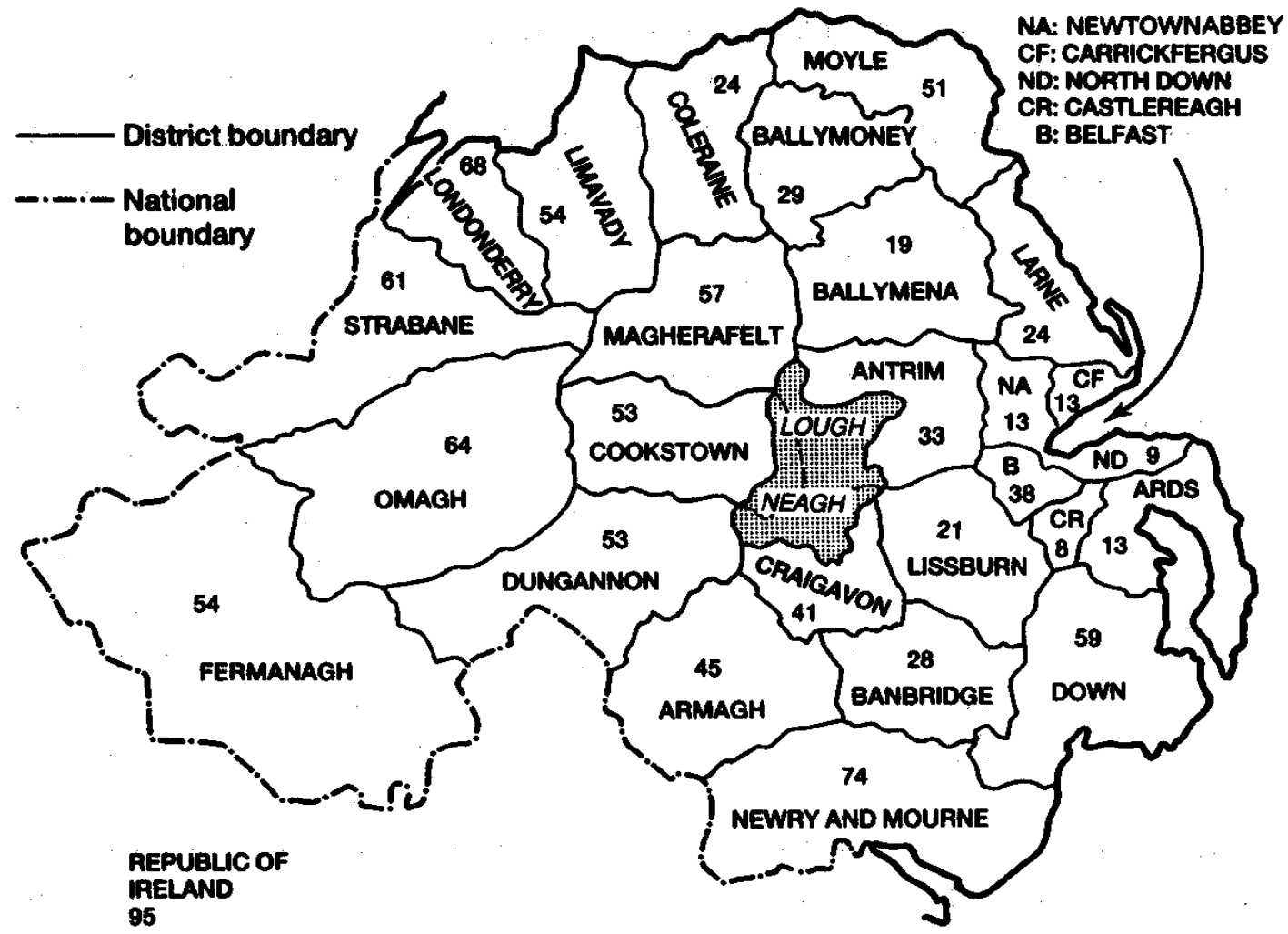

Figure 2: Northern Ireland 26 District Councils after 1973

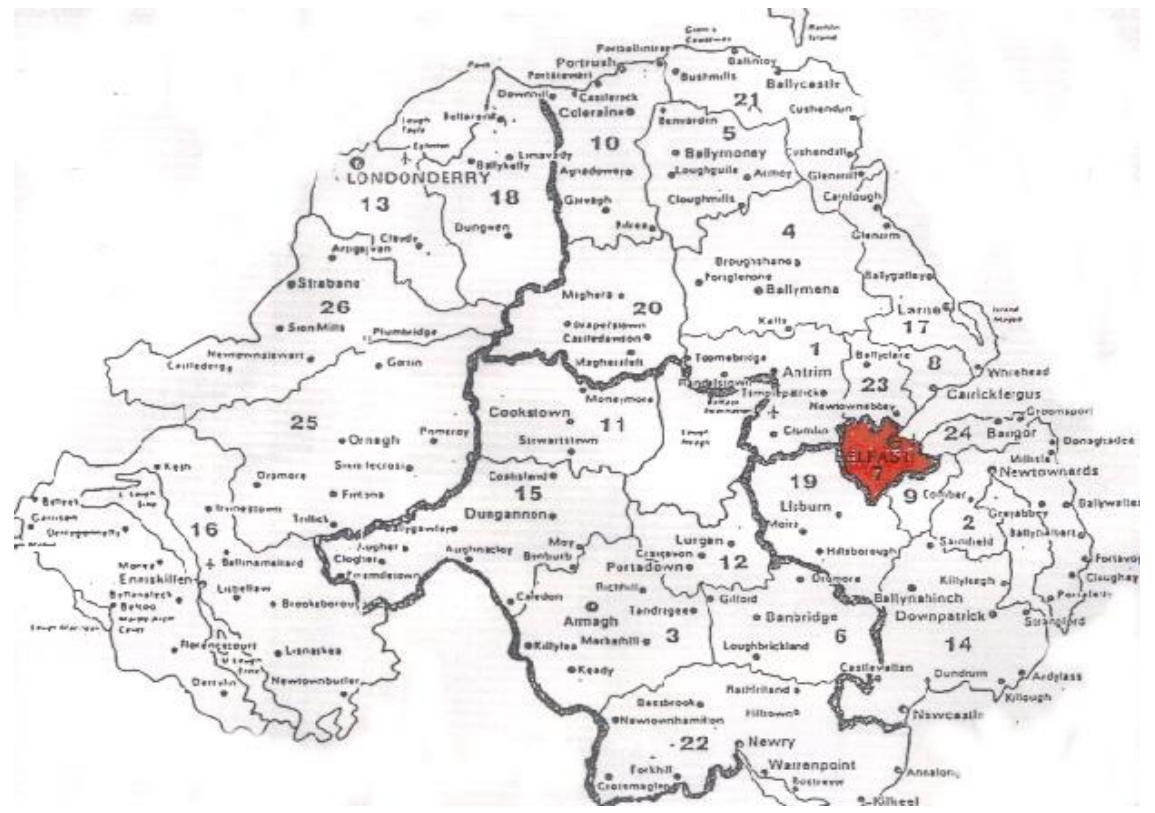

Solid Lines - Boundaries of the 5 Education and Library Boards 
Thin Lines - Boundaries of the 26 District Councils

Figure 3: Northern Ireland Education and Library Boards

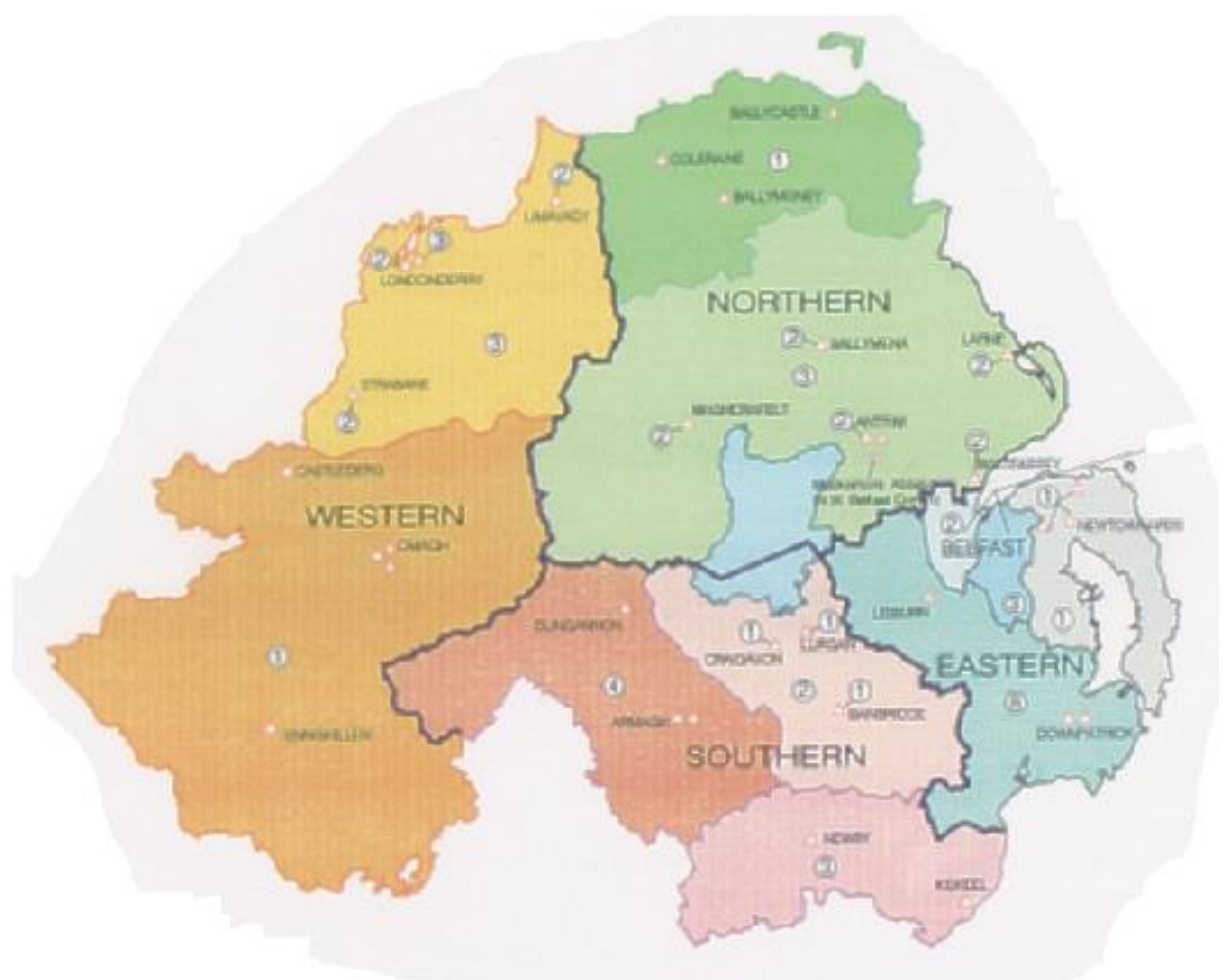

Solid Lines: Boundaries of the 4 Health and Social Services Area Boards Thin Lines: Sub-divisions/districts of the Health and Social Services Area Boards Figure 4: Northern Ireland Health and Social Services Area Boards 


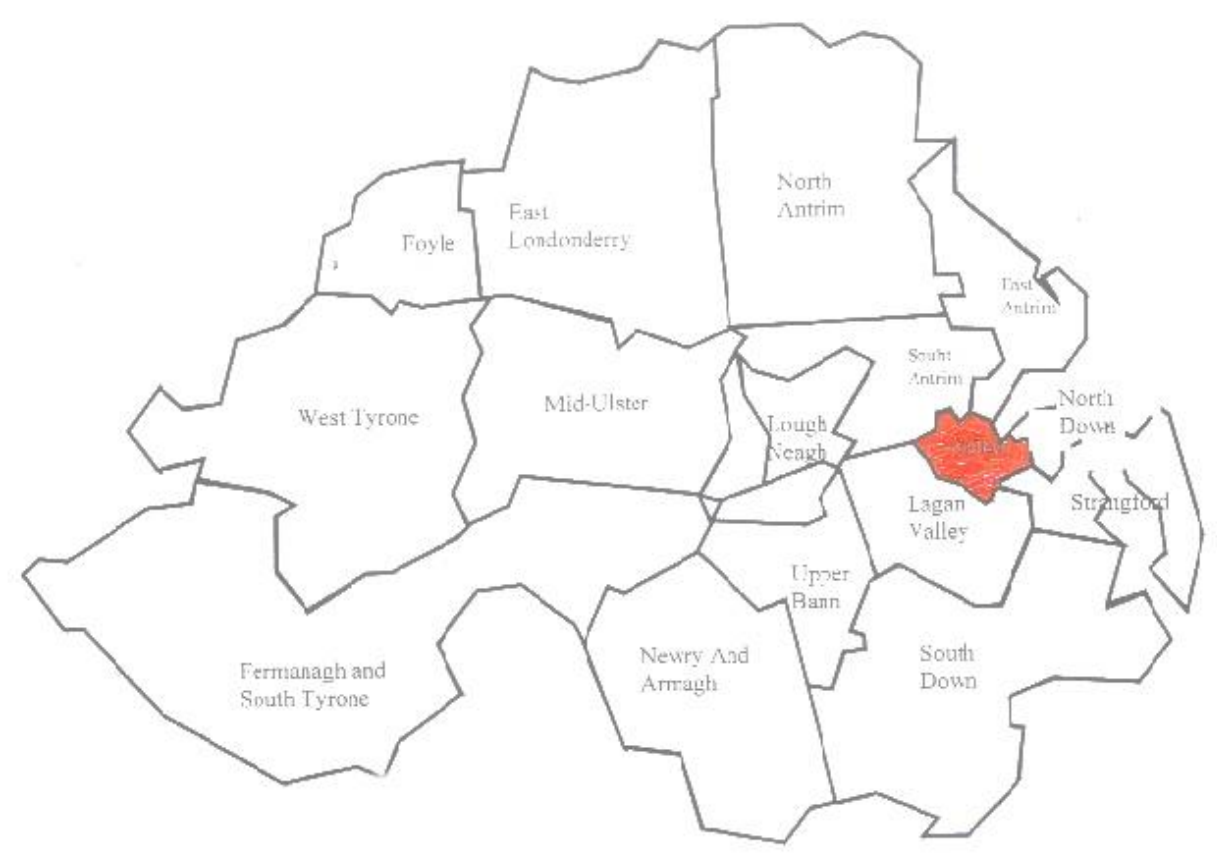

Figure 5: Northern Ireland Parliamentary Constituency Boundaries The Reform Process

Beyond contributing to peace, devolution also offered the prospect of dramatically rebalancing the political-administrative nexus (democratising the quangos/reinvigorating local councils). Indeed, this secondary dimension has assumed increasing prominence, given the continuing uncertainty over the fate of devolution. However, Northern Ireland's political masters were confronted with an immediate problem - should they assume that devolution will be restored or should any proposals for reform be adaptable to an extended period of Direct Rule. Indeed, should two alternative systems be planned. In the event, it fell to the devolved Executive to commence the process of brokering change.

Thus, a 'Review of Public Administration' (RPA) was launched on 24 June 2002. The origins of the RPA were in the Programme for Government in which the Executive 
pledged from the outset to "lead the most effective and accountable form of government in Northern Ireland" (NIG, 2001). David Trimble MLA, the then First Minister, argued:

The RPA is one of the major tasks facing the Executive and will be central to the way in which we deliver, structure and organize our public services in the future. This is the opportunity of a generation to put in place a modern, accountable, effective system of public administration that can deliver a high quality set of public services to our citizens. It is an opportunity we must take (Hansard, 25/2/02).

Northern Ireland has moved from a position of 'democratic deficit' to surfeit mode with 18 MPs, 108 MLAs, 582 local councilors and 3 MEPs. Aside from considerations of political representation, rationalizing the bureaucracy surrounding public service provision was central, as the Assembly struggled (devoid of tax-varying powers except the Regional Rate) to meet rising public expectations within a finite budget. The Assembly inherited a system of over 150 non-departmental public bodies (NDPBs) (with in excess of 2000 appointees). Just one example illustrates the problem. In education, as well as the Stormont Department of Education, there are five Education and Library Area Boards, the Governing Bodies' Association, the Irish Medium Schools' Body, the Northern Ireland Council for Integrated Education, the Regional Training Unit, the Council for Catholic Maintained Schools, and the Council for the Curriculum, Examinations and Assessment. In England, one LEA per area would normally suffice. As one trade unionist in the education sector remarked: "There is chronic over administration of schools in NI. A radical overhaul is required and this rebalance is long overdue" 
(Frank Bunting, NI Secretary, Irish National Teachers' Organisation, cited in Belfast Telegraph, "Overhaul needed "to get funds to schools", 6/5/04, p.7). To satisfy the requirements of a power-sharing executive, a cumbersome system of 11 government departments (to replace six) was also introduced.

The First and Deputy First Ministers suggested among the most important issues addressed by the review would be structure, accountability and responsibilities of local government, NDPBs and government agencies. Ministers agreed the Review is likely to have implications for the functions exercised by the Executive even if the institutions established by the Agreement and the division of functions were not to be considered. In general, politicians welcomed the Review, not least because there is a residual antiquango feeling overhanging from Direct Rule. A majority of MLAs are also local councillors and experienced at first hand relative powerlessness as elected representatives working on behalf of their constituents. The scope of the RPA has, however, proved controversial. Some politicians questioned the effectiveness of an exercise which excludes the Stormont departments, a theme articulated by trenchant critic of the Agreement, Robert McCartney MLA.

Everyone accepts that quangos, or many of them, must go and they should have gone long ago. They represented the veneer or cosmetic surface that several British Governments used to give a semblance of democratic accountability to Direct Rule. .... Everyone agrees that there must be a great pruning back. However, that disguises the fact that superimposed on top of a layer of 
undemocratic agencies was a layer that, in some respects, was little better devolved government (Hansard, 24/6/02).

These calls were rejected as seeking to "renegotiate the Agreement by the back door" and a distraction from main emphasis of the Review. Other reactions centred on how the Review should be undertaken. Calls for a 'Macrory II', i.e., an independent enquiry, were rejected. Unlike the 1960s and 1970s, when Governments preferred (Royal) Commissions, the Executive eschewed an independent enquiry. Instead, the Review is led by a multi-disciplinary team of officials in the Office of the First Minister and Deputy First Minister (OFMDFM), working with the advice of a team of independent experts (Tom Frawley, the NI Ombudsman, is in charge of the consultation process), and reporting to an Executive sub-committee. Concerns were expressed that a review led by officials from the OFMDFM amounted to regulatory capture by civil servants and the Executive, with independent experts offering only a façade of objectivity. Seamus Close MLA argued:

When politicians are seen to be examining themselves, and when they consult, the answer that comes back is invariably the answer that the politicians want to end up with, not the answer that the people demand. If we allow the OFMDFM or the Committee of the Centre to conduct this review, we will not get the result that the people who sent you here demand and deserve (Hansard, 25/2/04)

Moreover, the in-house management of the review prompted criticism that both proAgreement Executive parties and civil servants are keen to protect the configuration of 
both devolved political institutions and central government department, regardless of administrative logic.

\section{Challenges for the Review}

Several major challenges confronted the Review. Securing an appropriate level of political accountability demands hard choices about the future role of local government and NDPBs. There is a need to release and reassign resources within the restrictive Westminster-controlled Northern Ireland Block of public expenditure towards local, needs assessed, public service priorities. Simultaneously, however, it must also adhere to the principles of equality and human rights that form the heart of the Agreement. It must continue to adopt what is best in the modernizing agenda of New Public Management such as 'best value', responsiveness to customers, market awareness, being more entrepreneurial, structural de-layering and downsizing and promoting a shift from appointed to elected bodies. Among crucial questions figure: (1) What should be the optimal distribution of functions between the various tiers of government - regional, subregional and local? (2) If the view is that under devolution a number of the executive NDPBs need to be integrated into the mainstream departments or councils, how best should this be done? (3) Given the size of NI, could services be rationalized at two levels - Stormont and local government? (4) If so, how should those services be allocated and how many local authorities would be needed to deliver any proposed functions? 
Despite the suspension of the NI Executive and Assembly (now for the fourth time), Direct Rule Ministers have permitted - indeed, facilitated and encouraged the Review to continue in the hope, if not the expectation, that once devolution is restored, the momentum of reform can be maintained. Regardless of its outcome, the Review has trail blazed in its innovative efforts to achieve a thoroughgoing analysis of the wider public sector, including commissioning a series of specialist briefing papers, extensive consultations, omnibus surveys, as well as promoting widespread dissemination via the internet (for full details, see www.rpani.gov.uk).

A major challenge has concerned the scope of the review. Many politicians and senior civil servants regard the departmental structures established under the Agreement as sacrosanct while Stormont politicians, starved of executive authority under Direct rule, eschew any notion of local subsidiarity. The attitude of Stormont may exemplify bureau shaping behaviour by civil servants and politicians, whereby they use changes to organizational structures to enhance their own welfare. Consequently, buoyed by protection conferred by the in-built exclusion of government departments, some civil servants have been promoting the exercise as a 'review of local government' and 'culling councils' from 26 to 8,6 or even 5. Ironically, local government's centrality in the Review belies its small budget (5\% of the devolved block), limited scope for additional VFM savings, and self-evident democratic credentials. In truth, as former Deputy First Minister, Seamus Mallon MLA, remarked: "It is clear from the expenditure that local government is a crucial part of this. However it is only a part. The general administration is crucially important" (NIA Oral questions, 11/12/2000). 
Outwith Stormont, quangos and other public bodies have underscored the sense that the 'a review of local government' is afoot, given their remarkably low key reaction considering their own vulnerability to the Review's deliberations. Partly, lacking an organizing umbrella body, the case against such quangos often goes by default. Moreover, by contrast, local government has readily acquiesced in the 'review of local government' thesis. Galvanised through a newly created NI Local Government Association, the widespread feeling has been that 'our time has come'. Councils crave the opportunity to exert more influence over other public sector providers in their areas - a focus of accountability without necessarily having to take on the role of service deliverer although this thinking is often constrained by an inability to think outside the existing parameters of the present structures. It presupposes that the Review, like the devolution which precipitated it, automatically entails a revised and expanded role for councils when, as Scottish, Welsh and (potentially English) experiences illustrate, devolution frequently entails local government losing powers up to the devolved regional/national tier.

A further related challenge concerns the future of the Northern Ireland Civil Service's 25 Next Steps Agencies. Unlike their parent departments, Agencies are included in the Review, underscoring the point that this is a wider review of public administration, not simply local government. Accounting for c. $80 \%$ of civil servants, Agencies spend large sums of public money being integral to the functioning of government, providing several erstwhile local government services (such as water, roads, planning, and rates collection) 
(Carmichael, 2002). Therefore, a proper evaluation of their role and future is unavoidable if the Review's recommendations are to carry conviction. However, as yet, Agencies have been quietly sidestepped, a process to which Agencies have been willing accomplices. Already, one Agency (Training and Employment) has been reabsorbed into its parent department (Employment and Learning) following devolution on grounds of the latter's otherwise 'non-viable' situation. It seems likely that any recommendations for particular Agencies may well entail similar implications for their respective departments, in another example of how, whether intentional or not, the Review's recommendations will have spillover effects for the 11 central departments.

\section{Models for Reform}

In October 2003, the RPA team launched a public consultation document that set out five possible models for consideration in rethinking the structural architecture of public services. In keeping with the innovative theme of the Review process, the consultation document is user friendly. Echoing the "comprehensive vision" commended by the CDLR and academic literature, it sets out the principles of characteristics that any proposed new system of public administration must satisfy, reflects on ways in which we can deliver and improve public services (in particular, through enhanced mechanisms for accountability and participation) and offers five 'high-level' models for consideration on the future roles of central government, public bodies and local government. The five models are summarized thus:

1. Status quo: no change in the overall structure of public administration 
2. Centralised: all major services delivered directly by government departments.

3. Regional and sub-regional public bodies: a range of public bodies, operating either regionally or sub-regionally, would deliver public services

4. Reformed status quo with enhanced local government: while keeping the main features of the current system, democratically elected local authorities would be vested with new responsibilities.

5. Strong local government: major public services would be the responsibility of a smaller number of new local councils.

Interestingly, despite its remit, the Review adroitly intimates that it is likely to have implications for the functions exercised by the Executive.

Some 170 responses were made to the consultation document. No consensus emerged on what functions might be returned to councils but most of the main political parties endorsed models 4 and 5, with some wishing elements of model 3 to be included. In addition, an insistence on appropriate safeguards (in terms of minority protection etc) has been made, especially by nationalists, but also by Unionists (who form a minority in most councils in the West of the Province). These calls reflect longstanding deep-seated fears concerning the abuses of powers (especially of employment and housing allocations) that discredited the pre-1973 system of local government and which, indeed, did so much to stoke the embers of inter-communal tension that precipitated the Troubles. Reorganising councils is not without difficulties, however. While reference to American or European practice suggests that the reallocation of major quango functions to local government is perfectly plausible, the pervasive size-ism ('big is beautiful') that has informed 
successive local government reorganizations across the British Isles suggests an end product comprising fewer but larger councils and fewer major quangos, with their roles being effectively subsumed into the remit of enhanced local authorities - or of course government departments or agencies - however configured. Should reform proceed, the likelihood of bigger authorities emerging is much higher if Direct Rule remains rather than devolution given the widely shared local predilection for small units.

One key consideration with the proposals is the perceived threat posed by any substantially reinvigorated tier of local government to the devolved institutions. Simply, there may not be room for two major actors on the combined local/regional scene, redolent of how the former Belfast Corporation was often perceived as an upstart to the old Stormont. The touchpaper for conflict could be finance. Having been excluded from its initial remit, the Review has so far said nothing about financing an enlarged portfolio of local government functions. Currently, devoid of transparency, financial considerations are rarely understood by voters with the result that, while Northern Ireland ratepayers fare comparatively well compared with their counterparts in GB, there is a widespread feeling of being hard done by. A separate Rating Review exercise has proposed discarding the present rating system and a switch to one based on capital values (akin to the Council Tax in GB) (DFPNI, 2004). However, with some 80\% of Northern Ireland's district councils' income coming from the district rate (the remainder coming from the redistributed proceeds of the NI Regional Rate plus other central government grants), any major change in the functional responsibilities of local authorities threatens to seriously destabilize the basis of the high degree of (nominal) local financial 
accountability between citizen and council. Precisely because of their minor (and inexpensive) functions, the potential for financial accountability to local voters is much stronger than the altogether more tenuous link that exists in GB, where the gearing effect attenuates the direct link (though, in practice, like all voting in Northern Ireland, local elections invariably revert to type, i.e., a tribal headcount). However, without investing local authorities with a more robust source of locally derived revenue (such as local income tax - precluded by Westminster), new councils maybe far more dependent on Stormont grant with all its attendant consequences.

Given the continuing impasse in the efforts to resuscitate the fledgling devolved institutions, reviving local government may bypass the obstacles on the road to maintaining and building a (relatively) peaceful Northern Ireland. For sure, local councils have been actively engaged in the review process and a measure of their influence can be gleaned from the options proposed by the Review team in their consultation document. In some ways, after 30 years of constitutional experimentation amid political turbulence, local government has remained a stoically democratic forum albeit with tightly circumscribed powers. Its time may well have come. That said, not for the first time has such a proposition arisen, appearing previously as 'Model F' in a Government Working Paper (UK Government, 1979), only to be returned to the sagging shelf of failed initiatives within the NIO. 
Nonetheless, respecting the time-honoured practice of rehashing old ideas, in a rather preemptive press release (4 May 2004), the Minister, Ian Pearson, announced that "I see the final model including:

1. A significant reduction on the numbers of public bodies, including health service bodies;

2. Local councils being reduced from 26 to single figures, but having more powers, and boundaries that are fully aligned with other service providers in their locality;

3. Arrangements at a local level to ensure the maintenance of local identify and community input to decision-making; and

4. Robust governance arrangements to ensure transparent decision-making, fairness and the protection of minority interests".

Pearson added that the scale of the proposed reforms will inevitably require a lengthy implementation phase. While a final consultation report is anticipated by Spring 2005, the RPA announced a 7 council structure as the likely outcome. In achieving coterminosity of boundaries, each new unit would average some 250,000 inhabitants with a ceiling of 300,000 (www.rpani.gov.uk). The likely political control would be: 3 nationalist and 3 Unionist councils; Belfast would remain under no overall control. In what is "essentially a two tier model", the regional (i.e. upper) level would be responsible for policy development, strategic planning, setting standards of service delivery, monitoring that delivery, plus delivering regional services. "Most service delivery, however, would be at sub-regional level. Services will be delivered by new large, stronger Councils" working with "the local offices of regional service providers" (Pearson, 2004). 
With no short-term prospects for the Assembly's revival, Direct Rule ministers may be prepared to follow-through on this important issue. However, the spectre of the continued failure on the macro political front casts its long shadow. Coupled with the call for the mechanics of internal power sharing (as provided for in the Agreement) to be reconsidered, Peter Robinson, the DUP's Deputy Leader and erstwhile minister in the previous Executive, argued:

It is impossible to look at the Review of Public Administration outside the content of what is happening at the regional level. ... Clearly, arrangements which would be suitable in the absence of a devolved administration would not be suitable in the event of there being a return to devolution. ... There is a direct relationship between what arrangements we have at Stormont and what can be done at local government level (Robinson, 2003).

With the DUP now the driving force within Unionism, therefore, any serious movement on the RPA might seem inextricably linked with the wider constitutional situation.

\section{Evaluation}

No system of public administration is immutable. Shifts in social, economic and political circumstances demand periodic re-examination of existing sub-national governance (function, form, finance) to test its robustness to meet with the challenges posed of, and the expectations placed upon, it. In turn, there are concomitant effects upon the internal operation of individual state actors and the conduct of intergovernmental relations. 
Moreover, with the shift from welfare to regulatory state, there are consequences for the relations with the penumbra of other public, private, community and voluntary organizations into which each regional and local authority is networked. Cursory examination of international practice demonstrates the absence of uniformly accepted and applied criteria in devising and constructing structural configurations for government. Nonetheless, from our 'lessons for undertaking reform', several tentative conclusions can be drawn about how reform in Northern Ireland might be assessed.

Above all, if entirely predictably, politics is beginning to shape the reform agenda (and reaction to it) in terms of the possible future configuration of new sub-regional structures, their likely party political complexion, and the relative complexity of the emerging 'super' councils as they relate to Stormont. In the bitter context of Northern Ireland's polarised society, the imperative of raw political calculus is all the more acute. Nonetheless, other factors are discernible. Befitting the recent focus on structures of governance, there is a heavy emphasis on partnership both at council level with other providers (public, private, voluntary, community) as well as between the tiers of government - regional and sub-regional/local. This emphasis builds on the already extensive use of partnership arrangements in local government in respect of disbursing EU monies such as PEACE I and II. The 'bounding' concept is evident from the work reported by the Review team (www.rpani.gov.uk) with a particular stress placed on travel to work patterns in the derivation of tentative 6 and 7 council models. These models are borne of a gathering momentum for larger units of local government that reflects the pervasive size-ism familiar in Great Britain and, while contrary to expressions of local 
preference, epitomizes Direct Rule thinking. Contrary to 'organised chaos' of some economic theory, the fragmentation and overlap in many ways so characteristic of the present arrangements is eschewed in favour of consolidation through co-terminosity in the emerging proposals. Financing the proposals will also be a vexed issue not least because of the problems which have arisen in introducing water charges - local people (including a cross party consensus of politicians) want to know why they have 'to pay twice for water' arguing that the Regional Rate includes a charge for water services. Such public hostility and pledges of resistance including a non-payment campaign do not bode well for a complete review of the financing of local government as the public may well conclude that it has been conned - hardly the desired end product of any review.

Inevitably, of course, "no government starts with a tabula rasa - there are historical factors and the inertia of the status quo to be taken into account" (Kingdom, 1991, pp.378). Nowhere is the legacy of past events more telling than in Northern Ireland. Despite insidious and ongoing paramilitary violence, devolved government (should it be restored) and reformed local governance arrangements build in a degree of electoral accountability that reaffirms the wider popular desire for long-term stability and peaceful co-existence, albeit with different long-term political aspirations. Thus, while the fate of the Belfast Agreement itself remains uncertain and its implementation incomplete, a 30 year moratorium on long overdue administrative reform has at least been lifted. In breaking the impasse, the subsequent launch of the Review of Public Administration - and the determination to continue and conclude it before then implementing its recommendations - offers the prospect of partial improvement in the provision of public services, local 
public accountability and value for money. Ian Pearson, the Minister currently responsible, claimed the "Review of Public Administration is the most far-reaching examination of how public services should be delivered to citizens that I am aware of anywhere - apart, possibly, from Iraq" (Press Release, 4 March 2004). Whether the RPA merits the Minister's lofty claims can be debated. In many ways, its parameters have already constrained its outcomes. The failure to include a formal consideration of the central departments, or the thorny issue of finance, detracts from the RPA, though the implications for both cannot be sidestepped and, informally, are recognized as such. Certainly, the RPA has been comprehensive, the canvassing of public opinion exhaustive, and the output from the extensive engagement of independent research voluminous (see RPA website). Deficiencies notwithstanding, there is every prospect that a major overhaul and improvement of the system of sub-regional governance in Northern Ireland will help to compensate for inertia at the macro level. If, as a result, the local protagonists can work together cooperatively where hitherto they have proved incapable of so doing, there may yet be hope for political progress on the broader future of Northern Ireland. 


\section{Bibliography}

- Alexander A. (1982) The Politics of Local Government in the UK, Harlow: Longman.

- Bennett R. (ed.)(1989) 'Stimuli to administrative reform' in Bennett R. (ed.) Territory and Administration in Europe, London: Pinter.

- Bovaird T., Loeffler E., Parrado-Diez S. (2002) Developing Local Governance Networks in Europe, Baden Baden (Germany): Nomos Verlagsgebellschaft.

- Cameron, Lord (Chairman) (1969) Report of the Committee on Disturbances in Northern Ireland, Cmd.532 (NI), Belfast: HMSO.

- Carmichael P. (2002) 'The Northern Ireland Civil Service: Characteristics and Trends Since 1970’, Public Administration 80 (1) pp.23-49.

- Chandler J. (1991) Local Government Today, Manchester: Manchester University Press.

- CDLR (2001) Relationship between the size of local and regional authorities and their effectiveness and economy of their action, Report by the Steering Committee on Local and Regional Democracy, Strasbourg: Council of Europe.

- CDLR (2002) Administrative and Territorial Reforms Creating Territorial Communities or Authorities at Different Levels, Report by the Steering Committee on Local and Regional Democracy, Strasbourg: Council of Europe. (Steering Committee on Local and Regional Democracy) (www.coe.int/T/E/Legal_Affairs/Local_and_regional_Democracy/Steering_Com $\underline{\text { mittee) }}$ 
- Cram L. and Richardson J. (1993) Citizenship and local democracy: a European perspective, Warwick: European Public Policy Institute.

- Dente B. and Kjellberg F. (eds.)(1988) The Dynamics of Institutional Change: Local Government Reorganisation in Western Democracies, London: Sage.

- DFPNI (2004) Reform of the Domestic Rating System in Northern Ireland, Belfast: Department of Finance and Personnel, Rating Policy Division.

- Ditch J. and Morrissey M. (1979) 'Recent Developments in Northern Ireland's Social Policy', in Brown M. and Baldwin S. (eds.) The year book of social policy in Britain, London: Routledge and Kegan Paul.

- Hampton W. (1991) Local Government and Urban Politics, Harlow: Longman.

- Hayes M. (1967) 'Some Aspects of Local Government in Northern Ireland', in Rhodes E. (ed.) Public Administration in Northern Ireland, Londonderry: Magee College (University of Ulster).

- Kingdom J. (1991) Local Government and Politics in Britain, Hemel Hempstead: Philip Allan.

- Knox C.G. (1996) 'The Emergence of Power Sharing in Northern Ireland: Lessons from Local Government', Journal of Conflict Studies 16 (1) pp.7-29.

- Knox C.G (2003) 'Northern Ireland Local Government', in M.Callaghan and J.Keogan (eds.) Local Government in Ireland, Dublin: Institute of Public Administration.

- Ladner A. (2005) 'The United Kingdom: An Increasingly Differentiated Polity?' in Denters B. and Rose L.E. (eds.) Comparing Local Governance, Basingstoke: Palgrave. 
- Lammanais H.F.R. de (1848) Project de constitution de la Republique Francaise, Paris: Bureau du Peuple Constituant, cited in Bennett R. (ed.)(1989) 'Stimuli to administrative reform' in Bennett R. (ed.) Territory and Administration in Europe, London: Pinter.

- Macrory P. (1970) Review body on local government in Northern Ireland, Report, Cmd.540 (NI), Belfast: HMSO.

- MacKenzie W.J.M. (1961) Theories of Local Government, London: London School of Economics and Political Science.

- Mawson J. (1998) 'The Rise of the regional agenda to combat increased fragmentation', in Le Gales P. and Lequesne C. (eds) Regions in Europe, London: Routledge.

- NIG (1966) The Reshaping of Local Government: Statement of Aims, Cmd.517 (NI), Belfast: HMSO.

- NIG (1969) The Reshaping of Local Government: Further Proposals, Cmd.530 (NI), Belfast: HMSO.

- NIG (2001) Programme for Government, Belfast: Office of First Minister and Deputy First Minister.

- Norton A. (1994) International Handbook of Local and Regional Government, Aldershot: Edward Elgar.

- Office of the First Minister and Deputy First Minister (OFMDFM) (2005) The Review of Public Administration in Northern Ireland: Further Consultation. Belfast: OFMDFM. 
- Osborne R. and Shuttleworth I. (eds.)(2004) Fair Employment in Northern Ireland: A Generation On, Belfast: Blackstaff.

- Owens J. and Norregaard J. (1991) 'The Role of Lower Levels of Government: The Experience of Selected OECD Countries' in Owens J. and Panella G. (eds) Local Government: An International Perspective, Oxford: North Holland. Amsterdam: Elsevier.

- Pearson I. (2004) Ministerial Speech on the Review of Public Administration, Belfast (29 June). (http://www.rpani.gov.uk/290604speech.htm).

- Pierre J. and Peters B.G. (2000) Governance, Politics and the State, London: Macmillan.

- Pratchett L. (2004) 'Local Autonomy, Local democracy and the "New Localism"”, Political Studies 52 (2) pp.358-75.

- Review of Public Administration Website, www.rpani.gov.uk

- Rhodes R.A.W. (1997) Understanding Governance, Buckingham: Open University Press.

- Robinson P. (2003) Speech to Conference on Review of Public Administration, Stormont Hotel, Belfast, 3rd December 2003, www.dup.org.uk.

- Senior D. (1969) in Redcliffe-Maud, Lord (Chairman) Royal Commission on Local Government in England, Vol.II Memorandum of Dissent, Cmnd.4040-I.

- Sharpe L.J. (1988) 'Local Government Reorganisation: General Theory and UK Practice', in Dente B. and Kjellberg F. (eds.) The Dynamics of Institutional Change: Local Government Reorganisation in Western Democracies, London: Sage. 
- Stewart J. (2003) Modernising British Local Government, Basingstoke: Palgrave.

- Stoker G. (1989) 'Creating a local government for a post-Fordist society: the Thatcherite Project?', in Stewart J and Stoker G. (eds) The Future of Local Government, Basingstoke: Macmillan.

- UK Government (1979) The Government of Northern Ireland: A Working Paper for a Conference, Cmnd.7763 London: HMSO. 